\title{
Polar Compounds Isolated from the Leaves of Calea prunifolia H.B.K. and their Anti-Adrenergic Related Vasodilator Activity
}

\author{
Pilar Puebla, ${ }^{a}$ Nataly Aranguren, ${ }^{b}$ Javier Rincón, ${ }^{b}$ Maritza Rojas, ${ }^{b}$ Mario Guerrero ${ }^{*, b}$ \\ and Arturo San Feliciano ${ }^{a}$
}

\author{
${ }^{a}$ Laboratory of Organic and Pharmaceutical Chemistry, Faculty of Pharmacy, \\ Campus Miguel de Unamuno, Salamanca University, E-37007 Salamanca, Spain \\ ${ }^{b}$ Pharmacy Department, School of Sciences, National University of Colombia, AA 14490 \\ Bogotá D. C., Colombia
}

As folhas da Calea prunifolia H.B.K., espécie usada na medicina popular da Colômbia para a hipertensão, foram analisadas quanto à composição química, resultando no isolamento de um glicosídeo flavonóico, um derivado do ácido quínico e um glicosídeo diterpênico com esqueleto do tipo caurano. As estruturas químicas foram elucidadas por análise espectral, incluindo dados de HRMS e RMN 1D e 2D. A atividade anti adrenérgica dos três compostos foi avaliada. $\mathrm{O}$ efeito vasodilatador relacionado com a atividade anti adrenérgica dos três compostos foi avaliada em anéis de aorta isolada de ratos Wistar, contraídos cumulativamente com fenilefrina (de $1 \times 10^{-9}$ a $5 \times 10^{-5} \mathrm{~mol} \mathrm{~L}^{-1}$ ). Embora esses compostos não tenham apresentado atividade

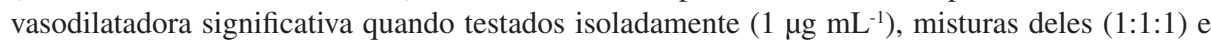
o próprio extrato de EtOH exerceu atividade anti adrenérgica preventiva, aumentando a $\mathrm{CE}_{50}$ da fenilefrina, de $2,3 \times 10^{-8}$ para $1,3 \times 10^{-7}$ e $8,0 \times 10^{-7} \mathrm{~mol} \mathrm{~L}^{-1}$, respectivamente.

The leaves of Calea prunifolia H.B.K., medicinal specie used in Colombian folk medicine for hypertension have been analysed for their chemical constituents, resulting in the isolation of one flavonoid glycoside, one quinic acid derivative and one kaurane diterpenoid glycoside. Their chemical structures were elucidated on the basis of spectral analysis, including HRMS, 1D- and 2D-NMR data. The vasodilator effect related to anti adrenergic activity of the three compounds was evaluated in isolated aortic rings from Wistar rats contracted cumulatively with phenylephrine (from $1 \times 10^{-9}$ to $5 \times 10^{-5} \mathrm{~mol} \mathrm{~L}^{-1}$ ). Although these compounds were devoid of significant vasodilator activity when they were tested alone $\left(1 \mu \mathrm{g} \mathrm{m}^{-1}\right)$, mixtures of them $(1: 1: 1)$ and the own EtOH extract exerted preventive anti-adrenergic activity increasing the phenylephrine $\mathrm{CE}_{50}$ from $2.3 \times 10^{-8}$ to $1.3 \times 10^{-7}$ and $8.0 \times 10^{-7} \mathrm{~mol} \mathrm{~L}^{-1}$, respectively.

Keywords: Calea prunifolia, kaurane diterpenoid glycoside, antiadrenegic activity, antihypertensive agents

\section{Introduction}

The genus Calea (Asteraceae, tribe Heliantheae, subtribe Melampodiinae) contains about 110 species, a great number of which occurs in Mexico, in Northern South America and Brazil. ${ }^{1}$ Calea prunifolia H.B.K. is a wild shrub known popularly as "carrasposa", ${ }^{2}$ in Colombia it grows principally in Caldas, Cundinamarca, Huila, Valle and Tolima Department and is used in folk Medicine for the treatment of arterial hypertension, high fever and malaria. ${ }^{3,4}$

*e-mail: mfguerrerop@unal.edu.co
Extensive phytochemical investigation on Calea prunifolia H.B.K has not been performed yet, and previous chemical investigation on this plant revealed the presence of sesquiterpenes derived from acorane, daucane and caleprunane, ${ }^{5}$ benzofuran derivatives,${ }^{6}$ chromenes, ${ }^{7}$ and sesquiterpene lactones, ${ }^{8}$ as the principal constituents.

This paper describes further investigations of the $\mathrm{EtOH}$ extract from the leaves of Calea prunifolia. We have now studied the polar fraction, which led to the isolation of three compounds, quercetin 3-rutinoside (1), ${ }^{9}$

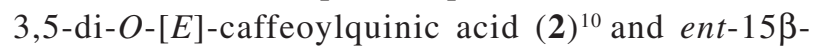
( $\beta$-D-glucopyranosyloxy)-kaur-16-en-19-oic acid 

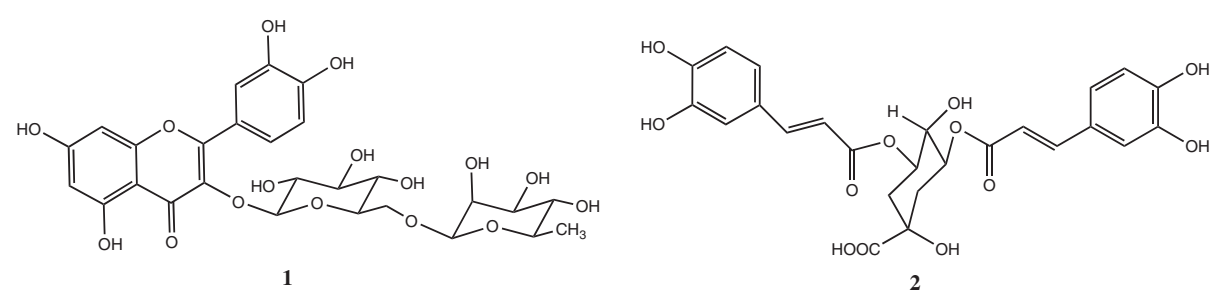

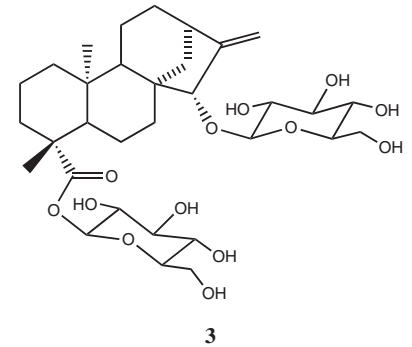

Figure 1. Structures of the isolated compounds 1-3.

$\beta$-D-glucopyranosyl ester (3) (Figure 1). All compounds were isolated from Calea prunifolia for the first time. The kaurane diterpenoid glycoside (3) is a new natural compound.

In a previous work Calea prunifolia $\mathrm{EtOH}$ extract showed antihypertensive and vasodilator effect in Wistar rats, related at least in part, to anti-adrenergic actions. ${ }^{11}$ Accordingly, this study assessed the effect of these compounds, alone and in a mixture, in isolated aortic rings stimulated with the alpha-1 adrenergic receptor agonist phenylephrine.

\section{Results and Discussion}

Repeated chromatography of the $n$-butanol soluble fraction from the ethanol extract of the leaves of Calea prunifolia led to the isolation of compounds 1-3. Their chemical structures were determined on the basis of complete spectroscopic analysis, including HR-ESI-MS, 1D- and 2D-NMR techniques and comparison with those reported in the literature.

Compounds $\mathbf{1}$ and $\mathbf{2}$ were identified as quercetin 3 -rutinoside and 3,5-di- $O$-[E]-caffeoylquinic acid respectively by comparison of its spectral data with those reported in the literature. ${ }^{9,10}$

Compound 3 gave a pseudomolecular ion peak at $\mathrm{m} / \mathrm{z}$ $665.3144[\mathrm{M}+\mathrm{Na}]^{+}$by HR-ESI-MS consistent with an elemental formula $\mathrm{C}_{32} \mathrm{H}_{50} \mathrm{O}_{13} \mathrm{Na}$. The IR spectrum indicated the presence of hydroxyl groups $\left(3400 \mathrm{~cm}^{-1}\right)$, an ester group $\left(1727 \mathrm{~cm}^{-1}\right)$ and a glycosidic moiety $\left(1000-1100 \mathrm{~cm}^{-1}\right)$. The molecular formula together with the overall aspects of the ${ }^{1} \mathrm{H}$ NMR spectrum and the counting of signals, analyzed below, in the ${ }^{13} \mathrm{C}$ NMR spectrum, readily suggested the presence of two sugar units attached to a diterpenoid. The ${ }^{1} \mathrm{H}$ NMR spectrum exhibited two signals for the protons of two quaternary methyl groups ( $\delta 0.96$ and 1.22$)$, also signals for one exocyclic methylene ( $\delta 5.08$ and 5.42), a methine bearing and oxygen atom $(\delta 4.01)$ and for two sugar anomeric protons $(\delta 4.42 \mathrm{~d} J 7.7)$ and $(\delta 5.40 \mathrm{~d} J 7.7)$, the last one typical of an ester-linked $\beta$-hexose suggested that two glycosidic units were present, while attached to different parts of the terpene unit.

The ${ }^{13} \mathrm{C}$ NMR spectrum aided by the HMQC experiment revealed the presence of signals for 32 carbons, including those for two methyl groups ( $\delta 16.7$ and 29.1), two anomeric carbons ( $\delta 95.6$ and 105.2), and one ester group $\left(\delta\right.$ 178.3). ${ }^{1} \mathrm{H}$ and ${ }^{13} \mathrm{C}$ NMR data revealed the occurrence of two $\beta$-glucopyranose units as sugar residues, one of them was attributable to the 19- $\beta$-glucopyranosyl ester and the set of signals of the other sugar fragment was associated to a $\beta$ - glucopyranoside of a secondary alcohol. ${ }^{12}$

The above spectral evidences suggested that compound 3 possessed a diglycosylated ent-kaurane skeleton.

The analysis of its ${ }^{1} \mathrm{H}-{ }^{1} \mathrm{H}$ correlated $\left({ }^{1} \mathrm{H}-{ }^{1} \mathrm{H}\right.$ COSY $)$, heteronuclear multiple-quantum coherence (HMQC) and the heteronuclear multiple-bond correlation (HMBC) spectra clarified the structure (Figure 2). The (H-1' C-19) and the (H-1" C-15) HMBC correlations suggested that the two $\beta$-glucopyranose units were attached each to the $\mathrm{C}-19$

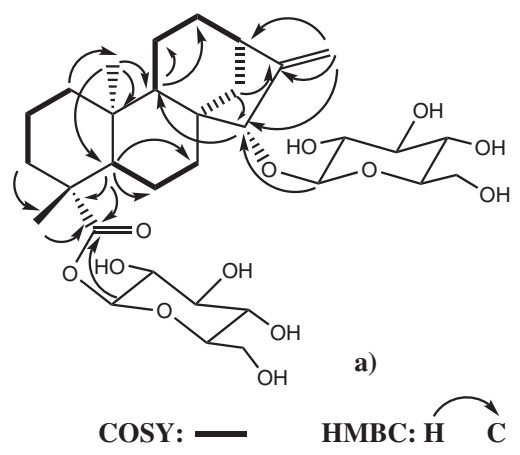

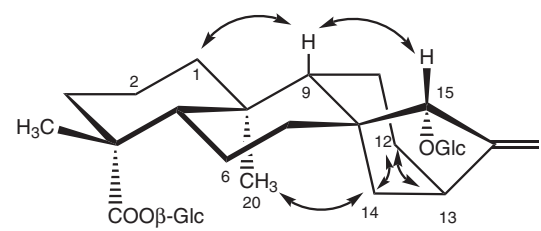

b)

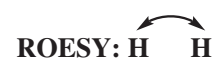

Figure 2. a) ${ }^{1} \mathrm{H}-{ }^{1} \mathrm{H}$ COSY and $\mathrm{HMBC}$ of compound 3. b) Key NOESY correlations of compound 3. 
and $\mathrm{C}-15$ positions of compound $\mathbf{3}$, as shown in Figure 2. Accordingly, the structure of $\mathbf{3}$ was assigned to that of ent-15-( $\beta$-D-glucopyranosyloxy)-kaur-16-en-19-oic acid $\beta$-D-glucopyranosyl ester. The ${ }^{1} \mathrm{H}$ and ${ }^{13} \mathrm{C}$ NMR data were in close proximity with those reported for paniculoside $\mathrm{V}$, isolated from different plants as Stevia paniculata and Francoeuria crispa. ${ }^{13,14}$ Significant differences were the chemical shifts of the signals assigned to C-8 (+3.6 ppm), C-13 (+2.9 ppm), C-14 (-2 ppm) and C-17 (+5.2 ppm), suggesting that 3 is the $\mathrm{C}-15$ epimer of paniculoside $\mathrm{V}$. The application of ${ }^{13} \mathrm{C}$ NMR spectroscopy to the structural elucidation of ent-kaurene-type diterpenes is well established. ${ }^{15}$ Signals due to the exocyclic methylene (C-17) appear at positions significantly different in $15 \alpha-$ and $15 \beta-\mathrm{OH}$ series. Such, in the $15 \alpha$ series resonates at $c a .104 \mathrm{ppm}$, while in the $15 \beta$ series resonates between $108-111 \mathrm{ppm}$, as in the case of compound 3 .

In addition, the signal of $\mathrm{H}-15$ in both $15 \alpha$ - and $15 \beta-\mathrm{OH}$ series also differs characteristically. In the $15 \alpha$ series appears as a doublet of doublets, while in the $15 \beta$ series resonates as a singlet and this is the case of compound $\mathbf{3}$. This hypothesis was further confirmed by a cross peak between the signals for H-15 and H-9 in the ROESY spectrum (Figure 2), supporting that the configuration of the glycoside at C-15 is $\alpha$ oriented. Accordingly, the structure of $\mathbf{3}$ was definitely established as ent-15 $\beta$-( $\beta$-D-glucopyranosyloxy)-kaur16-en-19-oic acid- $\beta$-D-glucopyranosyl ester (ent-kaurane IUPAC nomenclature), as shown in the drawing, which is described here for the first time.

C. prunifolia is among the medicinal species used in Colombian folk medicine for the treatment of hypertension. ${ }^{2}$ Vasodilator and antihypertensive effect related, at least in part, to some kind of antagonism to alpha adrenergic mechanisms has been previously described in Wistar rats. ${ }^{11}$ In order to assess the potential role of its polar components in the relaxant effect of this species, they were evaluated in isolated aortic Wistar rat rings contracted cumulatively with the alpha- 1 adrenergic receptor agonist phenylephrine (from $1 \times 10^{-9}$ to $5 \times 10^{-5} \mathrm{~mol} \mathrm{~L}^{-1}$ ). Their effects were compared with the elicited by the whole $96 \%$ EtOH extract and by the mixture of them $\left(1 \mu \mathrm{g} \mathrm{mL} \mathrm{m}^{-1}\right)$ each. The $\mathrm{E}_{\max }$ (100\% magnitude of contraction) induced by phenylephrine were $1337 \pm 95 \mathrm{mg}$ and the $\mathrm{EC}_{50}$ (concentration needed to attain $50 \%$ of contraction) was $23[15-36] \times 10^{-9} \mathrm{~mol} \mathrm{~L}^{-1}$ $(\mathrm{n}=36)$. The EtOH extract $\left(1 \mu \mathrm{g} \mathrm{mL} \mathrm{mL}^{-1}\right)$ significantly affected the contraction response induced by phenylephrine $\left(\mathrm{EC}_{50}\right.$ : increased to $8.0 \times 10^{-7} \mathrm{~mol} \mathrm{~L}^{-1}, \% \mathrm{E}_{\text {max }}$ decreased to $67.6 \pm 10.2$ ). Although compounds $\mathbf{1}, \mathbf{2}$ and $\mathbf{3}$ did not show important effects when they were tested alone, the mixture of them (1:1:1) increased the phenylephrine $\mathrm{EC}_{50}$ in some degree, from $23 \times 10^{-9}$ to $1.3 \times 10^{-7} \mathrm{~mol} \mathrm{~L}^{-1}$ (Figure 3).
It is possible to consider the presence of other bioactive principles in C. prunifolia but the polar compounds isolated in this study could play a role in the final effect. Hence, it seems to have support for the ethno medicinal use of C. prunifolia as a vasodilating and antihypertensive species and also to the idea of the existence of complementary or synergistic interactions between its polar components.

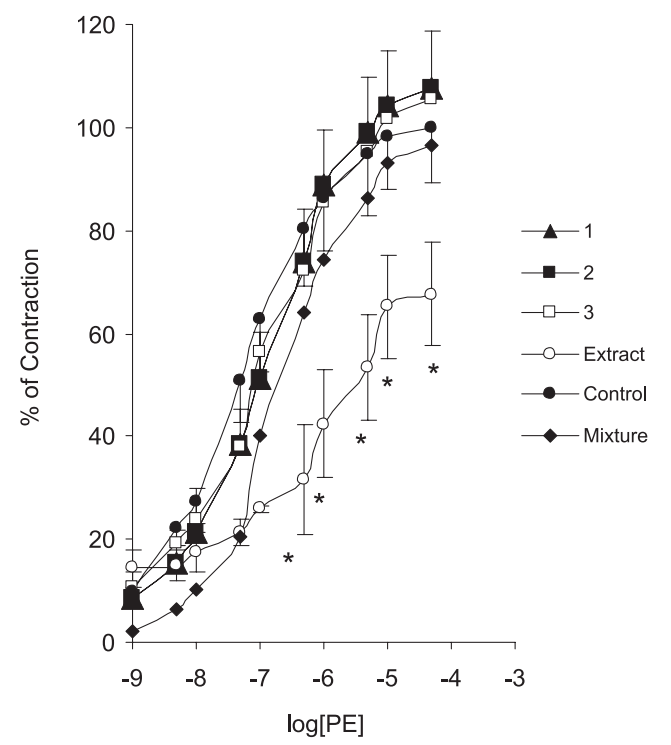

Figure 3. Concentration-response curves to phenylephrine (PE) (from $1 \times 10^{-9}$ to $5 \times 10^{-5} \mathrm{~mol} \mathrm{~L}^{-1}$ ) in Wistar rat aortic rings in absence (control) and presence of $1 \mu \mathrm{g} \mathrm{mL}^{-1}$ of the polar compounds $\mathbf{1}, \mathbf{2}$ and $\mathbf{3}$ isolated from $C$. prunifolia, the mixture of them and the whole $96 \%$ ethanolic extract. X-axis is expressed as PE logarithmic concentration. Data are the mean $\pm \mathrm{SEM} * \mathrm{p}<0.05$.

\section{Experimental}

\section{General experimental procedures}

IR spectra were obtained on a Nicolet Impact 410 spectrophotometer. ${ }^{1} \mathrm{H}$ NMR (200 and $400 \mathrm{MHz}$ ), and ${ }^{13} \mathrm{C}$ NMR (100 and $50 \mathrm{MHz}$ ) spectra were recorded on Brüker AC $200(200 \mathrm{MHz})$ and Brüker DRX $400(400 \mathrm{MHz})$ spectrometers, with TMS as an internal reference, $\delta$ given in ppm and $J$ in Hz. 2D-NMR spectra were measured with Brüker DRX 400 spectrometer. HRESIMS analysis, a VG-TS250 mass spectrometer $(70 \mathrm{eV})$ was used. Silica gel (230-400 mesh) for column chromatography and GF254 for TLC were obtained from Merck KGaA, 64271 Darmstadt, Germany. Sephadex LH-20 was obtained from Fluka, BioChemika Switzerland.

\section{Plant material}

The leaves of Calea prunifolia were collected in Cunday (Cundinamarca, Colombia) at an altitude of 1300 meters. 
A voucher specimen was identified and deposited in the Colombian National Herbarium, Natural Sciences Institute, National University of Colombia (COL), and the identity was confirmed by Dr. Edgar Linares (No. 468655/ COL000075582).

\section{Extraction and isolation}

The air-dried leaves of Calea prunifolia $(1.800 \mathrm{~kg})$ were extracted repeatedly with $96 \% \mathrm{EtOH}$ at room temperature. After removal of the solvent by evaporation in vacuo, the residue (201 g) was subsequently suspended in water and partitioned successively with $n$-hexane, $\mathrm{CH}_{2} \mathrm{Cl}_{2}, \mathrm{MeOH}$ and $n$-butanol. The $n$ - $\mathrm{BuOH}$ extract ( $39 \mathrm{~g}$ ) was subjected to silica gel flash column chromatography $(5 \mathrm{~cm}$ of diameter of column; 20 and $19 \mathrm{~g}$ of material, each column; using $20 \mathrm{~g}$ of silica gel per $1 \mathrm{~g}$ of material) and eluted with $2 \mathrm{~L}$ of $\mathrm{CH}_{2} \mathrm{Cl}_{2}-\mathrm{MeOH}(9: 1$ to $\mathrm{MeOH})$ to give three fractions that were further successively chromatografed in silica gel flash column chromatography and purified by Sephadex LH-20 column chromatography (using $10 \mathrm{~g}$ of Sephadex LH-20 per $1 \mathrm{~g}$ material), eluted with $n$-hexane- $\mathrm{CH}_{2} \mathrm{Cl}_{2}$ MeOH- $\mathrm{H}_{2} \mathrm{O}$ (2:2:1) to yield 3 compounds: 1 (40 mg), 2 $(35 \mathrm{mg})$ and $\mathbf{3}(60 \mathrm{mg})$.

Ent-15ß-( $\beta$-D-glucopyranosyloxy)-kaur-16-en-19-oic acid $\beta$-D-glucopyranosyl ester (3)

White amorphous solid. mp: $170-173{ }^{\circ} \mathrm{C}$ IR; (film) $v_{\max } / \mathrm{cm}^{-1}: 3400,1727,1637,1514,1050 ;{ }^{1} \mathrm{H}$ NMR $\left(\mathrm{CD}_{3} \mathrm{OD}, 400 \mathrm{MHz},\right) \delta 0.83(\mathrm{~m}, 1 \mathrm{H}), 0.96(\mathrm{~s}, 3 \mathrm{H}), 1.07$ $(\mathrm{m}, 1 \mathrm{H}), 1.08(\mathrm{~m}, 1 \mathrm{H}), 1.13(\mathrm{~m}, 1 \mathrm{H}), 1.22(\mathrm{~s}, 3 \mathrm{H}), 1.41$ $(\mathrm{m}, 2 \mathrm{H}), 1.42(\mathrm{~m}, 1 \mathrm{H}), 1.56(\mathrm{~m}, 2 \mathrm{H}), 1.60(\mathrm{~m}, 1 \mathrm{H}), 1.70$ $(\mathrm{m}, 1 \mathrm{H}), 1.80(\mathrm{~m}, 2 \mathrm{H}), 1.98(\mathrm{~m}, 2 \mathrm{H}), 2.0(\mathrm{~m} 2 \mathrm{H}), 2.20$ (m, 1H), 2.65 (br s, 1H), 3.25-3.45 (m, 7H), $3.70(\mathrm{~m}, 2 \mathrm{H})$, 3.83 (d, 1H, J $9.0 \mathrm{~Hz},), 3.87$ (d, 1H, J 9.0 Hz,), 4.01 (s, 1H), $4.42(\mathrm{~d}, 1 \mathrm{H}, J 7.7 \mathrm{~Hz}),, 5.08(\mathrm{~s}, 1 \mathrm{H}), 5.42(\mathrm{~s}, 1 \mathrm{H}, \mathrm{s})$, $5.40(\mathrm{~d}, 1 \mathrm{H}, J 7.7 \mathrm{~Hz},) ;{ }^{13} \mathrm{C}$ NMR $\left(\mathrm{CD}_{3} \mathrm{OD}, 100 \mathrm{MHz}\right) \delta$ $16.7,19.5,20.2,22.2,29.1,33.8,37.0,37.7,39.0,41.2$, 42.0, 43.6, 45.1, 50.0, 55.4, 58.8, 62.4, 63.0, 71.1, 71.9, $74.0,75.8,77.8,78.2,78.7,90.6,95.6,105.2,111.5$, 158.0, 178.3; HR-ESI-MS m/z: $665.03144[\mathrm{M}+\mathrm{Na}]^{+}$ (Calc. for $\mathrm{C}_{32} \mathrm{H}_{50} \mathrm{O}_{13} \mathrm{Na}, 665.3143$ ).

\section{Rat aortic rings assays}

Male Wistar rats (250-350 g) from the bioterium of Pharmacy Department, School of Sciences, University of Colombia, were anaesthetized with ether and sacrificed. The descending thoracic aorta was dissected and placed in an oxygenated Krebs solution with the following composition (in mmol L-1): $\mathrm{NaCl}, 118.0 ; \mathrm{KCl}, 4.75 ; \mathrm{CaCl}_{2}$,
$1.8 ; \mathrm{MgSO}_{4}, 1.2 ; \mathrm{KH}_{2} \mathrm{PO}_{4}, 1.2 ; \mathrm{NaHCO}_{3}, 25 ;$ glucose, 11 and ascorbic acid 0.1 . Rings of thoracic aorta $(4-6 \mathrm{~mm}$ in length) were carefully excised and submerged in organ chambers containing $10 \mathrm{~mL}$ of Krebs solution of bathing medium maintained at $37{ }^{\circ} \mathrm{C}$ and bubbled with $95 \% \mathrm{O}_{2}$ and $5 \% \mathrm{CO}_{2}$ gas mixture ( $\mathrm{pH}$ 7.4). Rings were mounted by means of two parallel L-shaped stainless-steel holders inserted into the lumen. One holder served as an anchor while the other was connected to a force-displacement transducer (Fort-10, WPI) to measure isometric contractile force recorded by an analog-digital conversion system (lab-trax/8-WPI). The rings were stretched progressively to an optimal basal tension of $2 \mathrm{~g}$, determined by lengthtension relationship experiments and then allowed to equilibrate for $60 \mathrm{~min}$ time with bath fluid being changed every 15-20 min. After this incubation time, phenylephrine was cumulatively added in 0.5 concentration logarithmic units, from $1.0 \times 10^{-9}$ to $5.0 \times 10^{-9} \mathrm{~mol} \mathrm{~L}^{-1}$. The procedure was done in absence (control) and presence of $1 \mu \mathrm{g} \mathrm{mL}^{-1}$ of each one of the compounds. This concentration was chosen according to previous reported work with the whole EtOH extract from $C$. prunifolia. ${ }^{11}$ DMSO $(<0.01 \%)$ was the vehicle used.

Responses were calculated as a percentage of the maximal contraction induced by phenylephrine, and were computer fitted to a sigmoidal curve using nonlinear regression to allow the calculations of $\mathrm{EC}_{50}$ values. The results are expressed as means \pm SEM of $n>5$. Analysis of variance was used to evaluate the results. $p<0.05$ was considered to indicate significance. GraphPad (4.0; San Diego, CA, USA) and Excel (Office 2010, Microsoft ${ }^{\circledR}$ ) software were used for data analysis.

In all of these experiments, the provisions regarding the protection of animals used for experimental purposes in current Colombia legislation (Law 84 and resolution 8430, Ministry of Health and Social Protection) were applied.

\section{Conclusions}

The chemical investigation of the leaves of Calea prunifolia has resulted in the isolation of three compounds: quercetin 3-rutinoside (1), 3,5-di- $O$ - $[E]$-caffeoylquinic acid (2) and ent-15 $\beta$-( $\beta$-D-glucopyranosyloxy)-kaur-16-en-19oic acid $\beta$-D-glucopyranosyl ester (3). These compounds are being reported for the first time in this species, and are important for the chemotaxonomy of Asteraceae family. The kaurane diterpenoid glycoside (3) is a new natural compound. Complementary or synergistic interactions between these polar compounds seem to play a role in the anti-adrenergic related vasodilator effect induced by this species. 


\section{Supplementary Information}

Supplementary data including physical data for compounds 1-3 and 1D- and 2D-NMR are available free of charge at http://jbcs.sbq.org.br as a PDF file.

\section{Acknowledgments}

The authors thank the financial support of VRI/DIB, National University of Colombia to the project No. 8003027.

\section{References}

1. Wussow, J. R.; Urbatsch, L. E.; Sullivan, G. A.; Syst. Bot. 1985, 10, 241.

2. García Barriga, H.; Flora Medicinal de Colombia, Botánica Médica, Mundo Ed.: Bogotá, Colombia, 1992.

3. Cabrera, I.; Memorias I Simposio Colombiano de Etnobotánica, CISEC: Santa Marta, Colombia, 1987.

4. Garavito, G.; Rincón, J.; Arteaga, L.; Hata, Y.; Bourdy, G.; Giménez, A.; Pinzón, R.; Deharo, E.; J. Ethnopharmacol. 2006, 107, 460 .

5. Castro, V.; Jakupovic, J.; Bohlmann, F.; J. Nat. Prod. 1984, 47, 802 .
6. Ober, A. G.; Fronczek, F. R.; Fischer, N. H.; J. Nat. Prod. 1985, $48,242$.

7. Ober, G. A.; Urbatsch, L. E.; Fischer, N. H.; Phytochemistry 1985, 24, 795.

8. Castro, V.; Tamayo-Castillo, G.; Jakupovic, J.; Phytochemistry 1989, 28, 2415.

9. Kazuma, K.; Noda, N.; Suzuki, M.; Phytochemistry 2003, 62, 229.

10. Pauli, G. F.; Poetsch, F.; Nahrstedt, A.; Phytochem. Anal. 1998, 9, 177.

11. Onzaga, I.; Rincón, J.; Guerrero, M.; Colomb. Med. 2008, 39, 33.

12. Kasai, R.; Suzuo, M.; Asakawa, J.; Tanaka, O.; Tetrahedron Lett. 1977, 175.

13. Yamasaki, K.; Kohda, H.; Kobayashi, T.; Kaneda, N.; Kasai, N.; Tanaka, O.; Nishi, K.; Chem. Pharm. Bull. 1977, 25, 2895.

14. Abdel-Mogib, M.; Jakupovic, J.; Dawidar, A. M.; Metwally, M. A.; Abou-Elzahab, M.; Phytochemistry 1990, 29, 2581.

15. Yamasaki, K.; Kohda, H.; Kobayashi, T.; Kasai, N.; Tanaka, O.; Tetrahedron Lett. 1976, 1005.

Submitted: March 31, 2011

Published online: September 6, 2011 


\section{Polar Compounds Isolated from the Leaves of Calea prunifolia H.B.K. and their Anti-Adrenergic Related Vasodilator Activity}

\section{Pilar Puebla, ${ }^{a}$ Nataly Aranguren, ${ }^{b}$ Javier Rincón, ${ }^{b}$ Maritza Rojas, ${ }^{b}$ Mario Guerrero ${ }^{* b}$ and Arturo San Feliciano ${ }^{a}$}

${ }^{a}$ Laboratory of Organic and Pharmaceutical Chemistry, Faculty of Pharmacy,

Campus Miguel de Unamuno, Salamanca University, E-37007 Salamanca, Spain

${ }^{b}$ Pharmacy Department, School of Sciences, National University of Colombia, AA 14490

Bogotá D. C., Colombia

Quercetin 3-rutinoside (1)

Yellow amorphus solid. mp: $230-233{ }^{\circ} \mathrm{C} ;{ }^{1} \mathrm{H}$ NMR $\left(\mathrm{CD}_{3} \mathrm{OD}, 200 \mathrm{MHz}\right) \delta 1.01(\mathrm{~d}, 3 \mathrm{H}, J 6.2 \mathrm{~Hz}),, 3.05-$ $3.80(\mathrm{~m}, 10 \mathrm{H}), 4.40(\mathrm{~m}, 1 \mathrm{H}), 5.0(\mathrm{~d}, 1 \mathrm{H}, J$ 7,3 Hz, ), 6.08 (d, 1H, J $1.8 \mathrm{~Hz}$ ), 6.27 (d, 1H, J $1.8 \mathrm{~Hz}$ ), 6.76 (d, $1 \mathrm{H}, J 8.4 \mathrm{~Hz}), 7.54(\mathrm{dd}, 1 \mathrm{H}, J 2.2 ; 8.4 \mathrm{~Hz}),, 7.77(\mathrm{~d}, 1 \mathrm{H}$, $J 2.2 \mathrm{~Hz}) ;{ }^{13} \mathrm{C}$ NMR $\left(\mathrm{CD}_{3} \mathrm{OD}, 50 \mathrm{MHz}\right) \delta 17.8,68.4,69.6$, 71.3, 72.0, 72.1, 73.8, 75.6, 77.1, 78.1, 94.8, 99.9, 102.3, $104.6,105.5,115.9,117.6,123.0,123.5,135.5,145.7$, $149.7,158.4,159.2,162.8,165.9,179.3$.
3,5-di-O-[E]-caffeoylquinic acid (2)

Yellow oil. ${ }^{1} \mathrm{H}$ NMR $\left(\mathrm{CD}_{3} \mathrm{OD}, 400 \mathrm{MHz}\right) \delta 2.79(\mathrm{~m}$, 2H), 2.94 (m, 2H), 4.50 (m, 1H), $5.97(\mathrm{~m}, 1 \mathrm{H}), 6.05(\mathrm{~m}$, 1H), 6.96 (d, 1H, J $15.8 \mathrm{~Hz}$ ), 7.04 (d, 1H, J $15.8 \mathrm{~Hz}$,), 7.54 (d, 1H, J $8.1 \mathrm{~Hz}$ ), 7.55 (d, 1H, J 8.1 Hz,), 7.73 (dd, $1 \mathrm{H}, J 1.9 ; 8.1 \mathrm{~Hz}$ ), 7.81 (d, 1H, J $1.9 \mathrm{~Hz}$ ), 8.21 (d, 1H, $J 15.8 \mathrm{~Hz}$ ), 8.25 (d, 1H, $J 15.8 \mathrm{~Hz}$ ); ${ }^{13} \mathrm{C}$ NMR (DMSO, $100 \mathrm{MHz}) \delta 35.1,36.3,68.5,71.2,71.4,73.2,114.7,114.9$ (2), 115.3, 116.3 (2), 121.9, 122.1, 126.5, 126.6, 145.4 (2), $145.8,146.0,148.6,148.7,166.4,167.0,175.9$

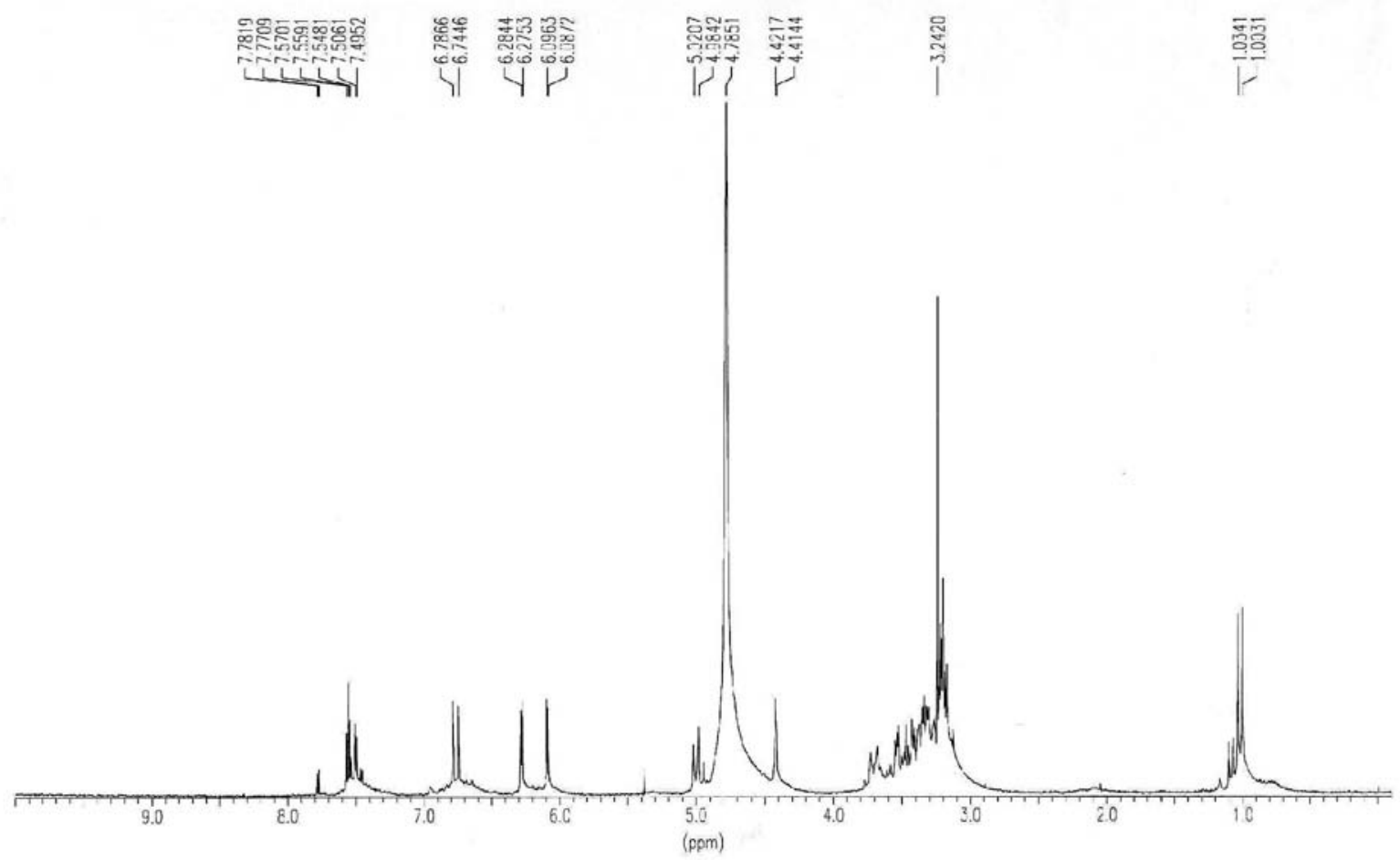

Figure S1. ${ }^{1} \mathrm{H}$ NMR $\left(\mathrm{CD}_{3} \mathrm{OD}\right)$ spectrum of compound $\mathbf{1}$. 
1.4.

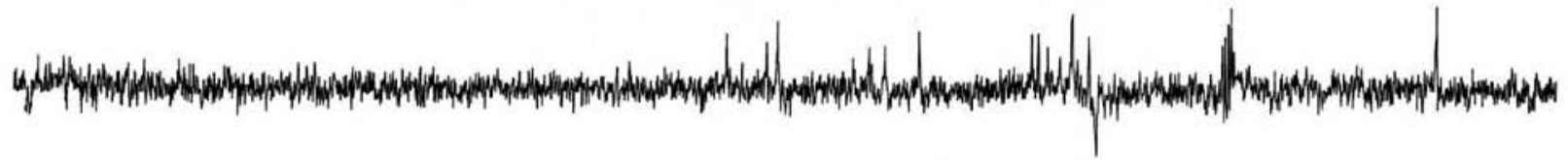

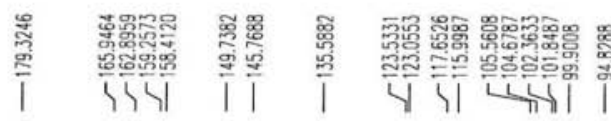
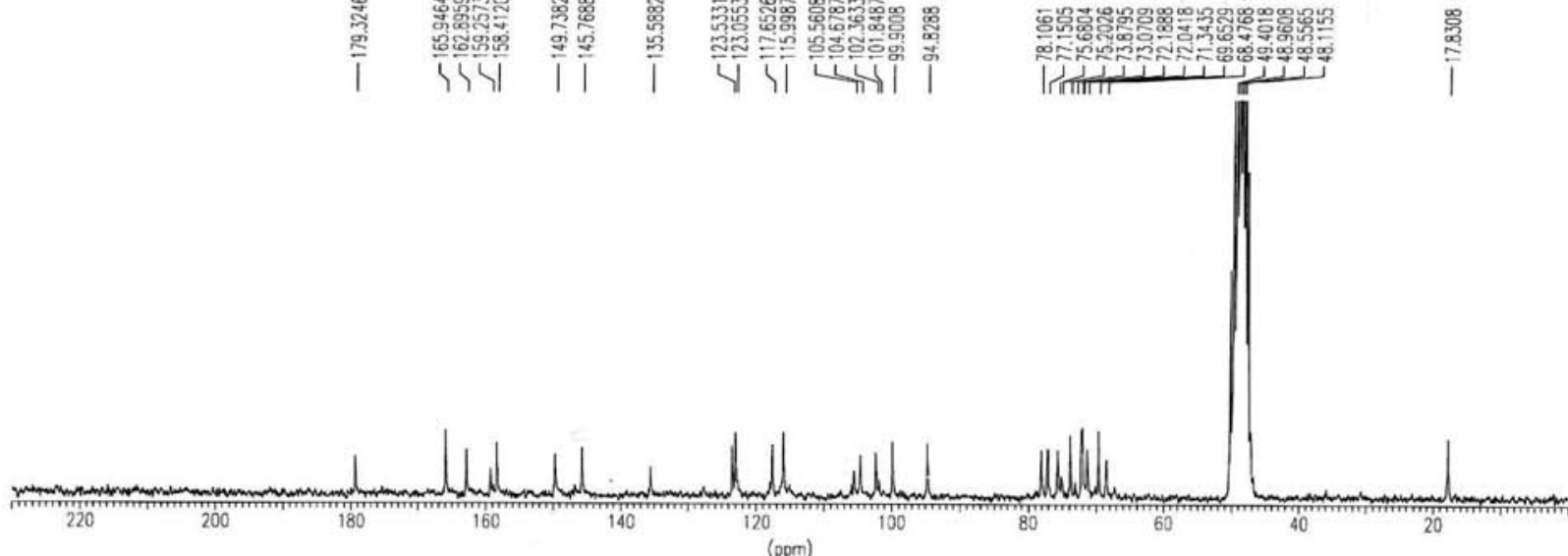

Figure S2. ${ }^{13} \mathrm{C}$ NMR $\left(\mathrm{CD}_{3} \mathrm{OD}\right)$ spectrum of compound $\mathbf{1}$.

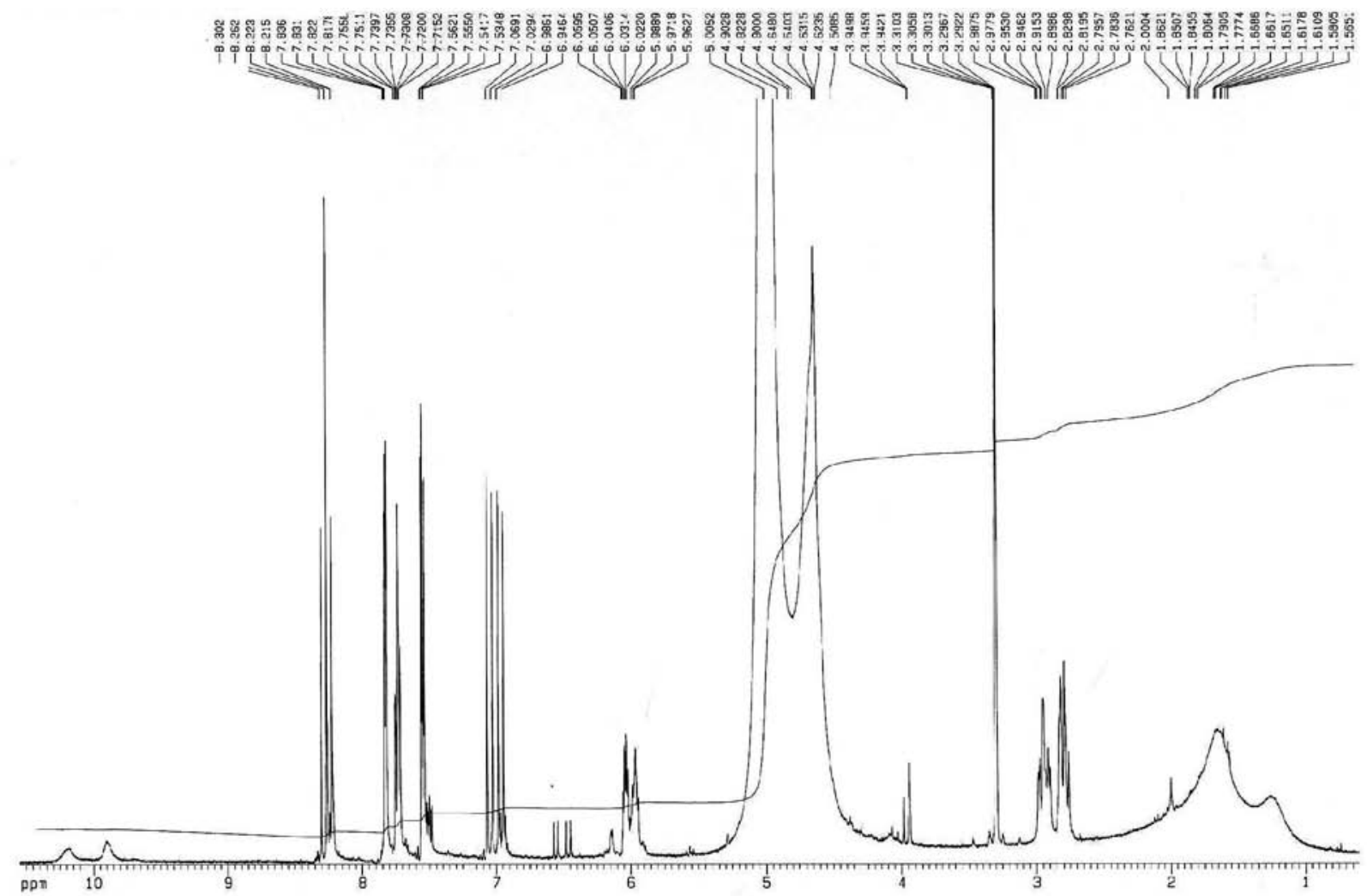

Figure S3. ${ }^{1} \mathrm{H} \mathrm{NMR}\left(\mathrm{CD}_{3} \mathrm{OD}\right)$ spectrum of compound 2. 


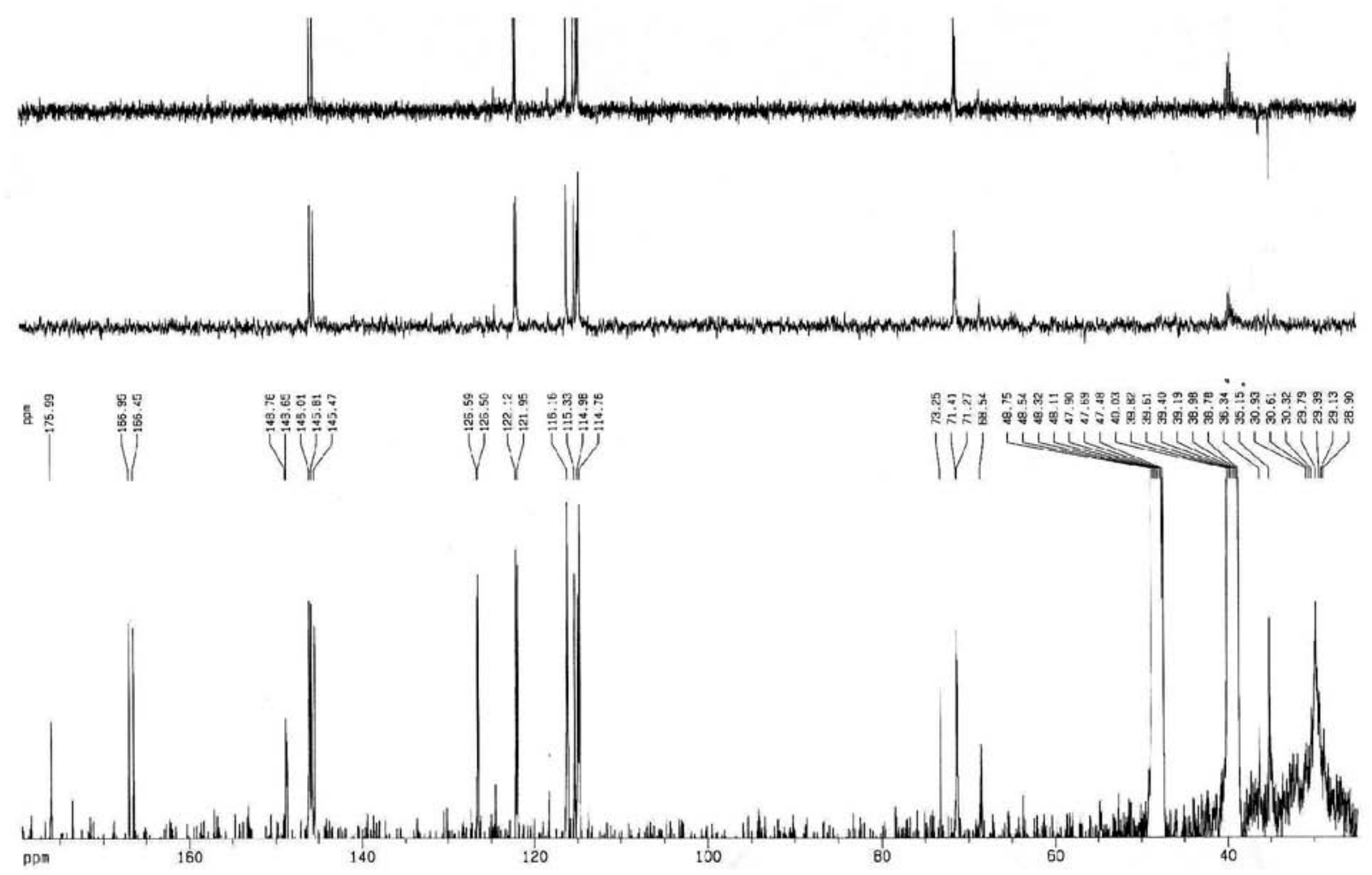

Figure S4. ${ }^{13} \mathrm{C}$ NMR (DMSO) spectrum of compound 2.
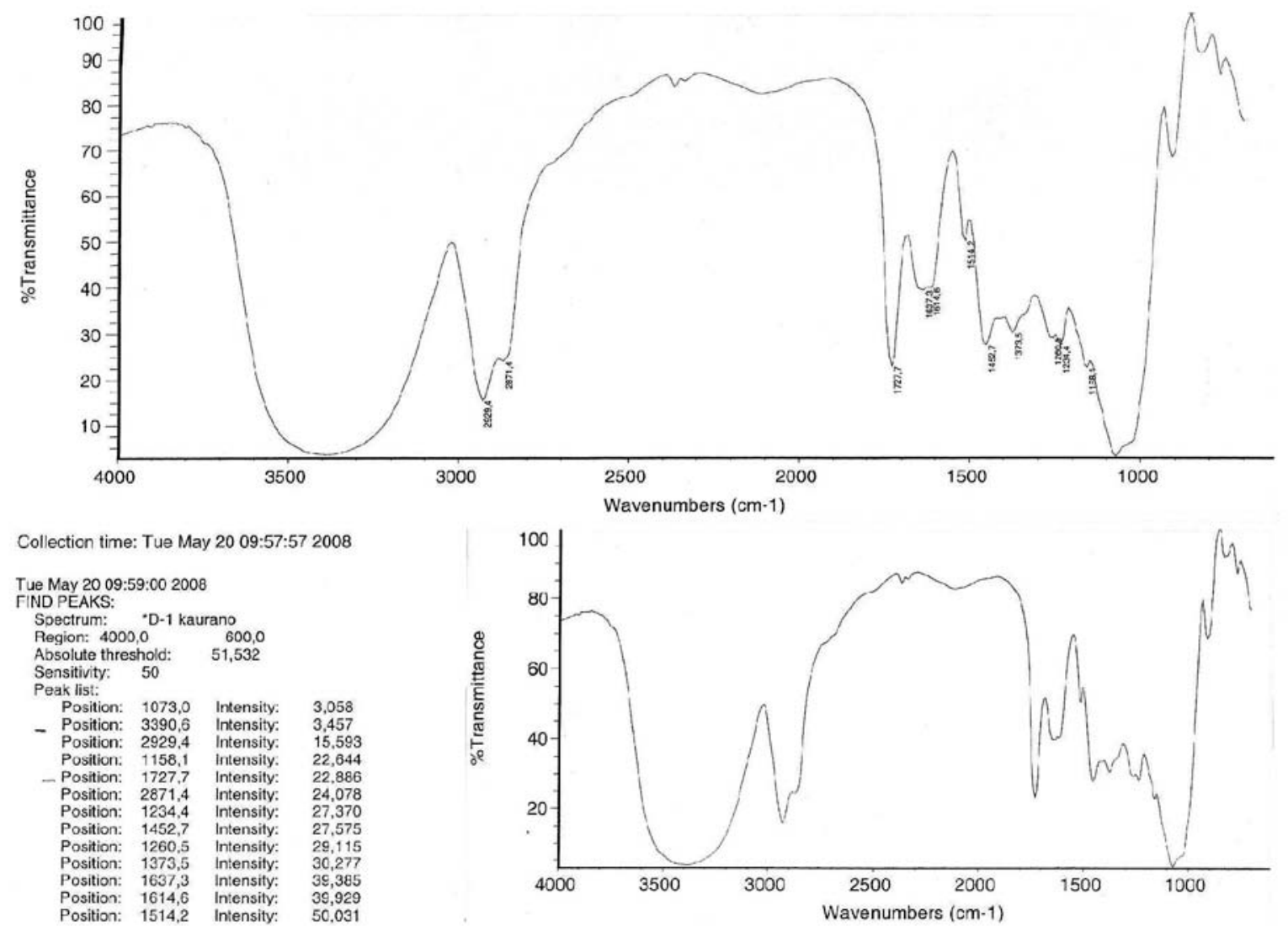

Figure S5. IR (film) spectrum of compound 3. 


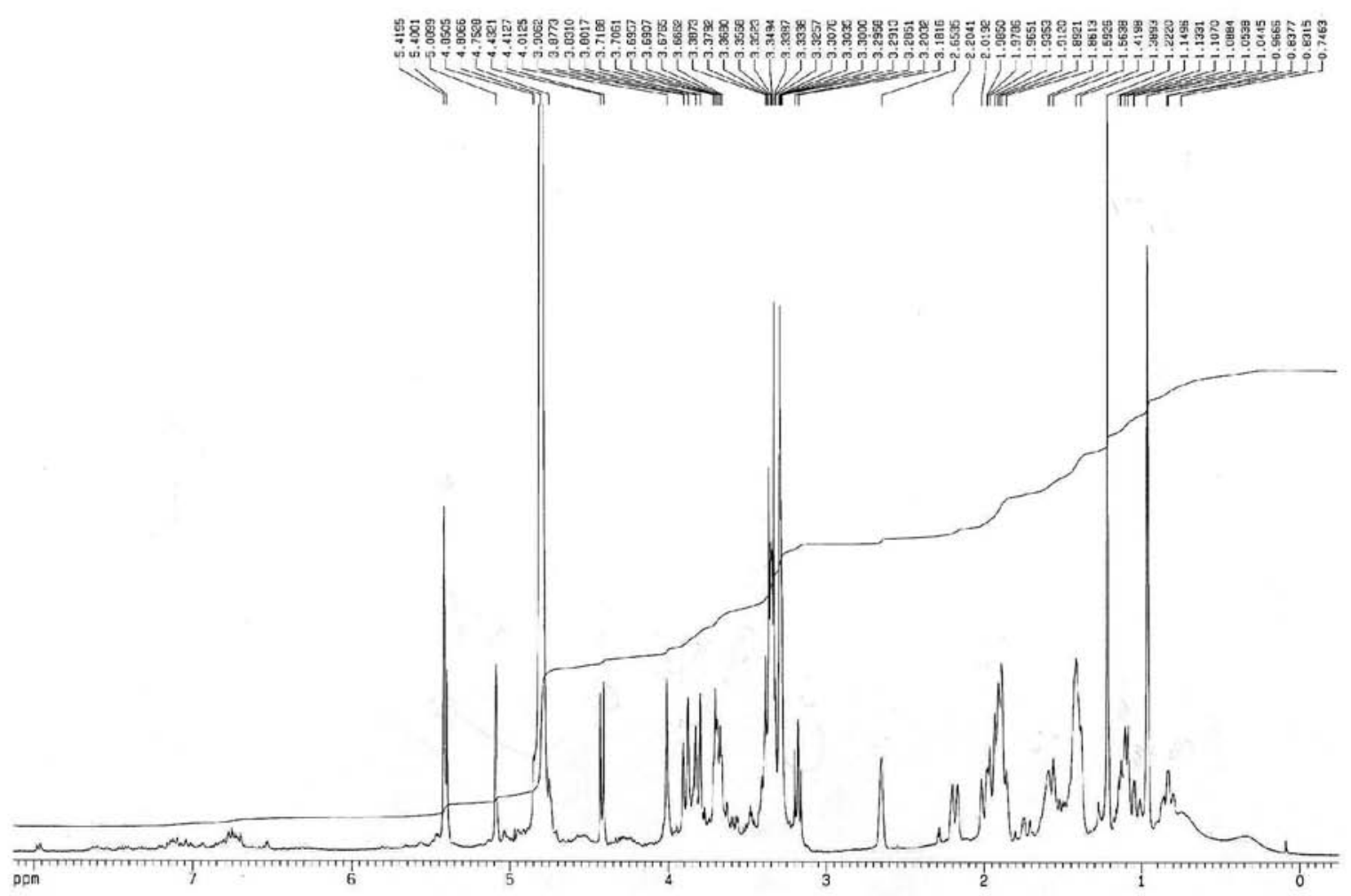

Figure S6. ${ }^{1} \mathrm{H}$ NMR $\left(\mathrm{CD}_{3} \mathrm{OD}\right)$ spectrum of compound $\mathbf{3}$.
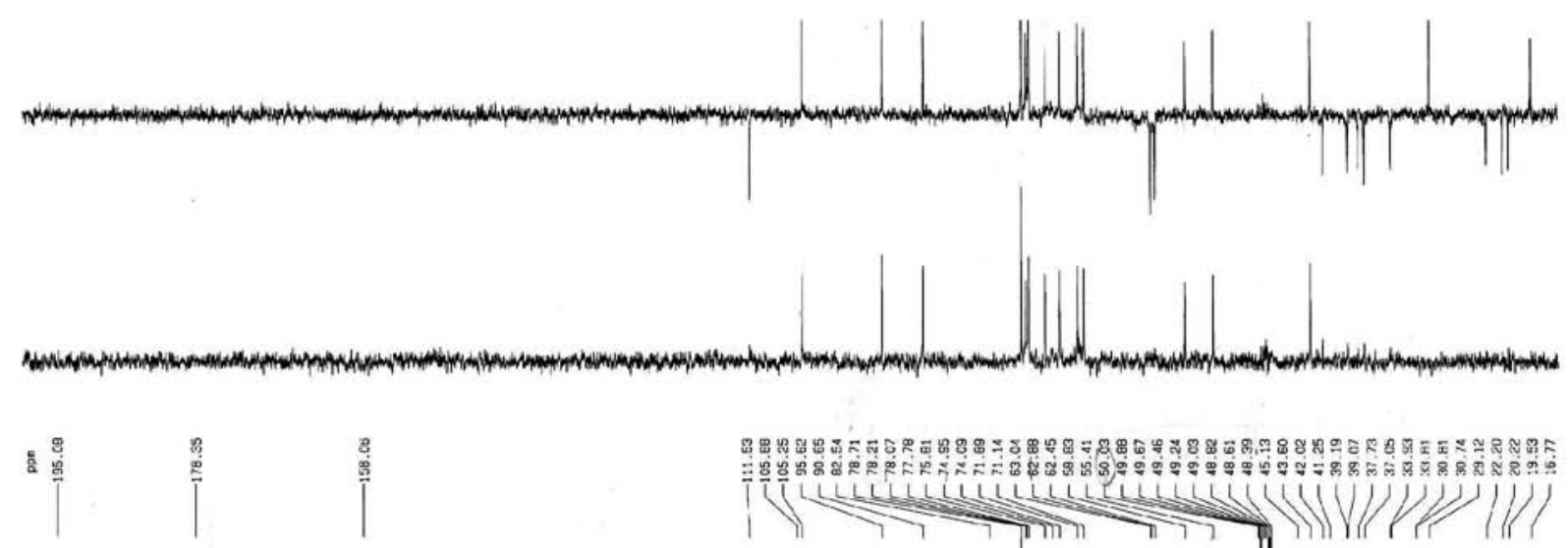

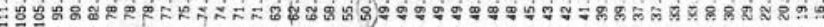

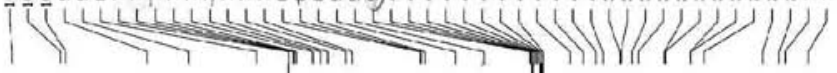

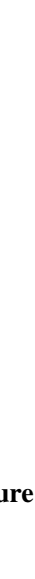




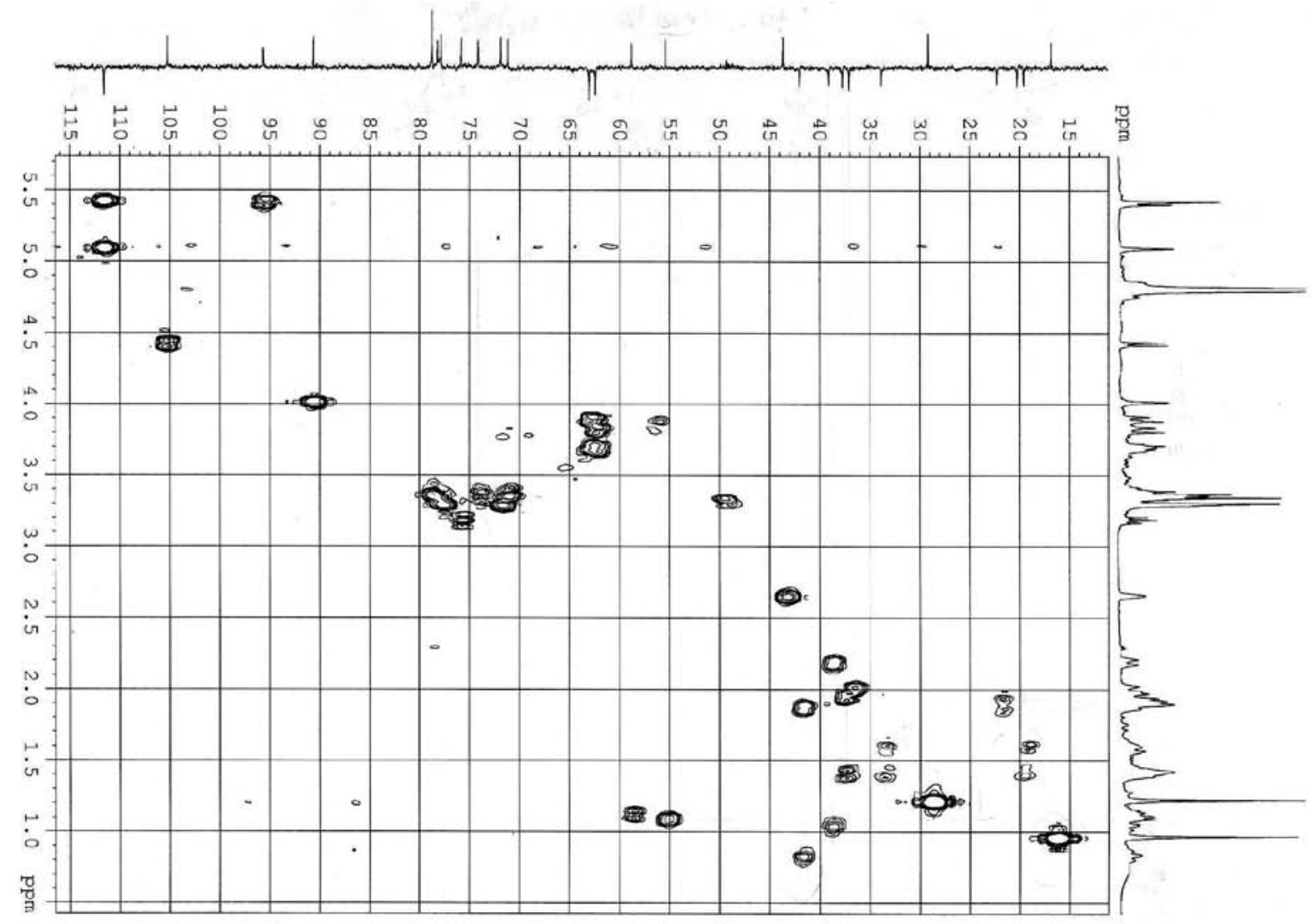

Figure S8. HMQC spectrum of compound 3.

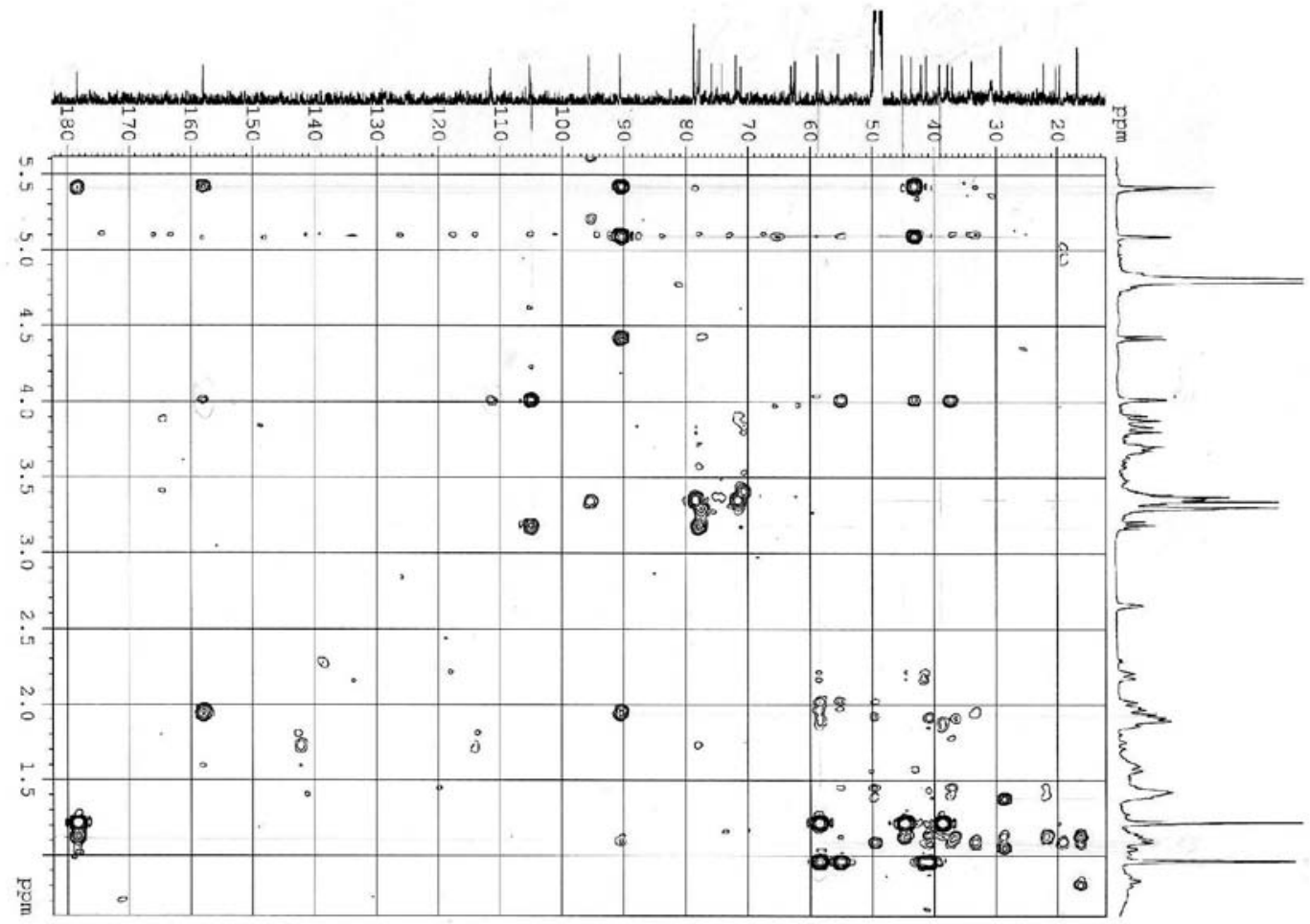

Figure S9. HMBC spectrum of compound 3 . 


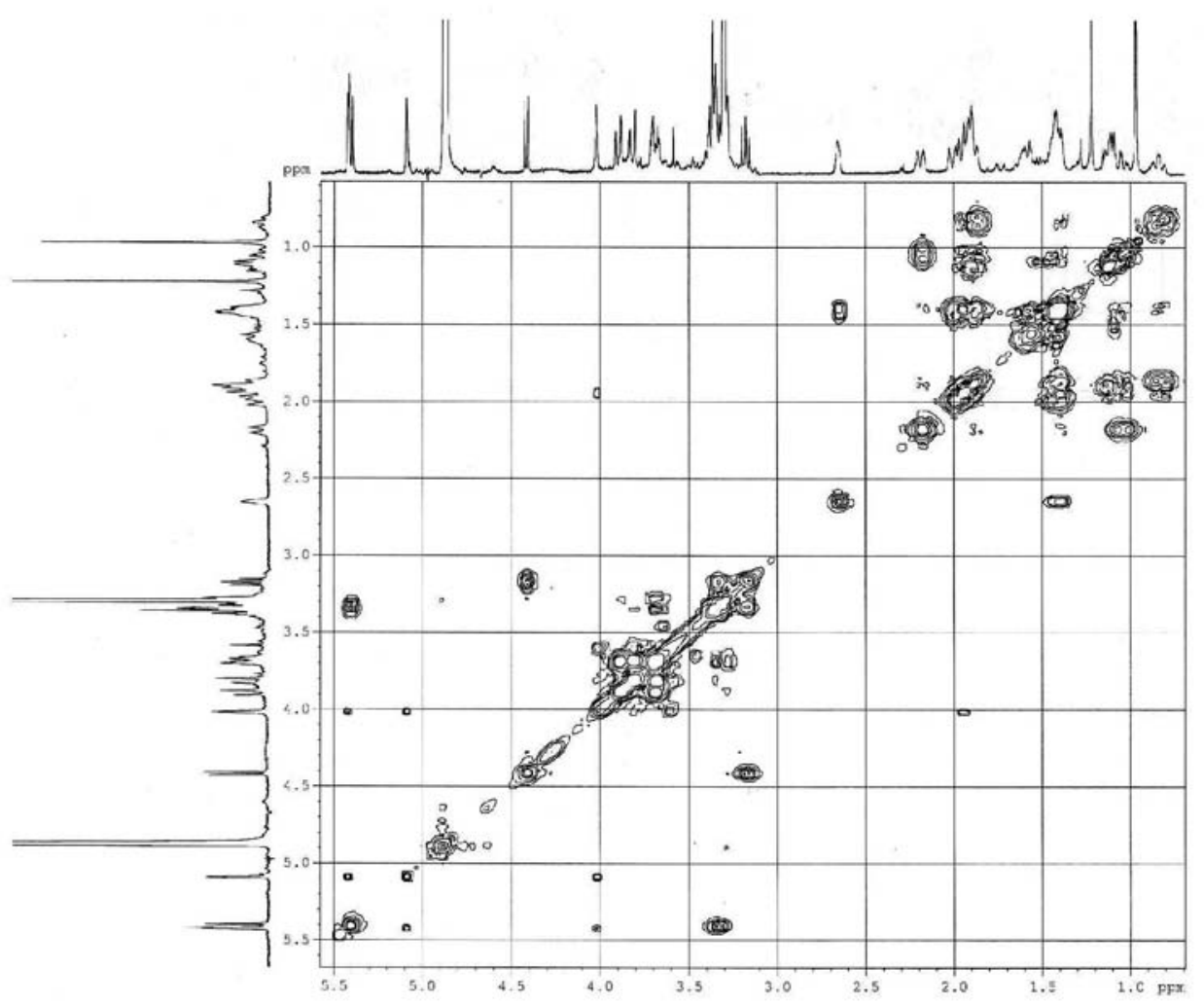

Figure S10. COSY spectrum of compound 3.

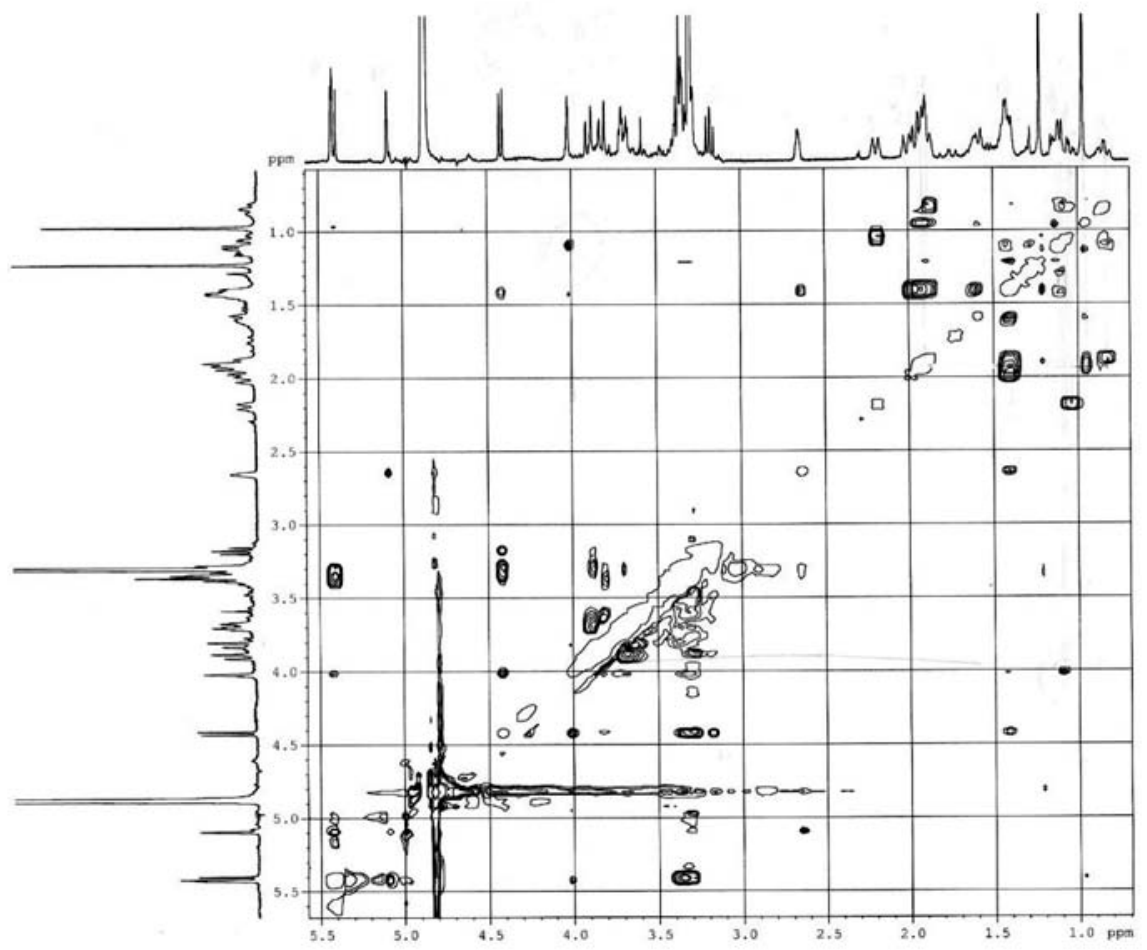

Figure S11. ROESY spectrum of compound 3. 


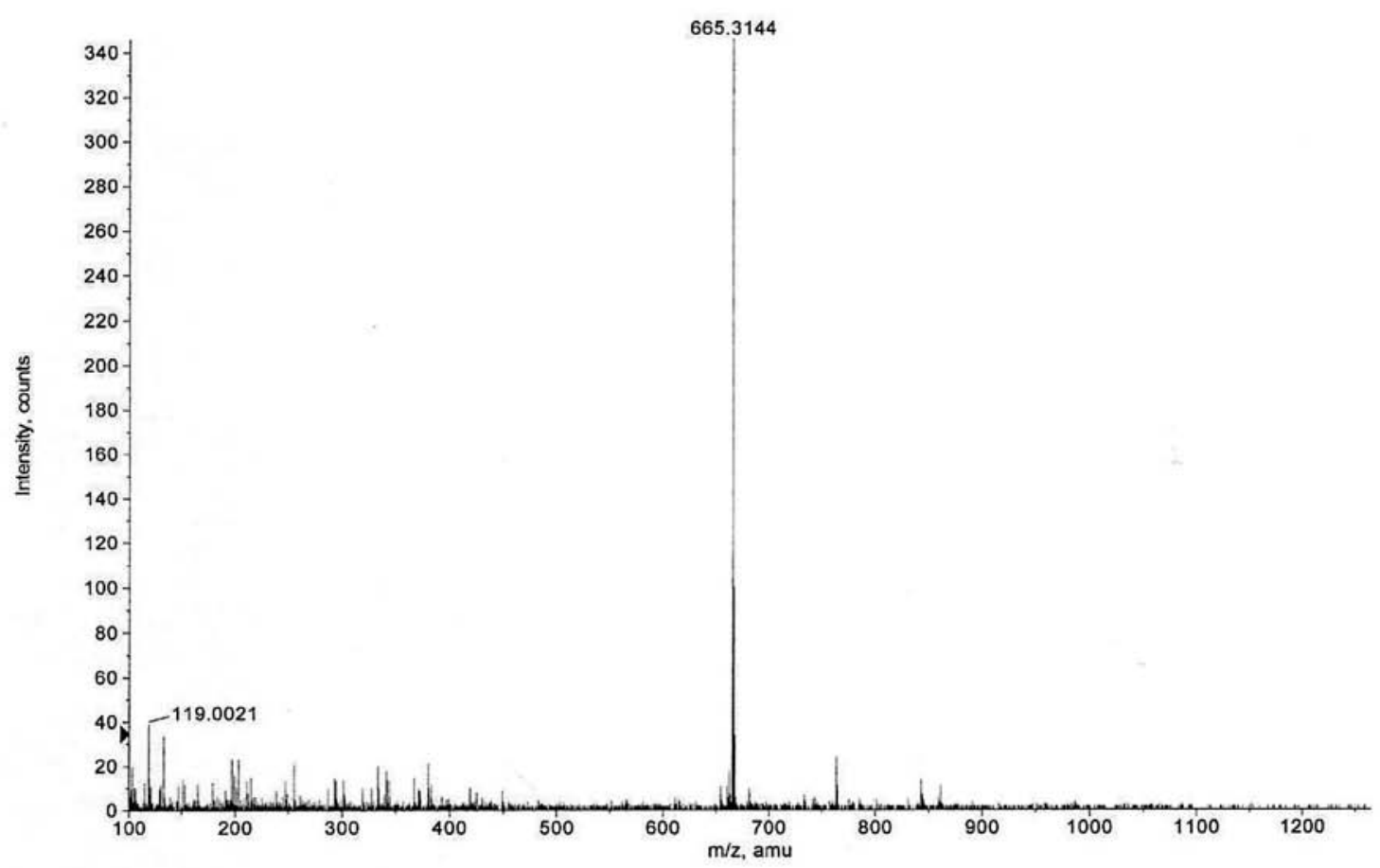

\begin{tabular}{lrrrr}
\hline Formula & CalculatedMass & mDaError & ppmError & RDB \\
\hline C32 H50 O13 Na & 665.314363 & 0.03656 & 0.054951 & 7.5 \\
C30 H45 N6 O11 & 665.314083 & 0.316692 & 0.476003 & 11.5 \\
C45 H42 N2 O2 Na & 665.31385 & 0.549904 & 0.826532 & 25.5 \\
C43 H37 N8 & 665.31357 & 0.830036 & 1.247584 & 29.5 \\
C31 H41 N10 O7 & 665.315421 & -1.02062 & -1.53404 & 16.5 \\
C33 H46 N4 O9 Na & 665.315701 & -1.300752 & -1.955092 & 12.5 \\
C29 H42 N10 O7 Na & 665.313015 & 1.38464 & 2.08118 & 13.5 \\
C29 H49 N2 O15 & 665.312746 & 1.654004 & 2.486047 & 6.5 \\
C47 H41 N2 O2 & 665.316255 & -1.855356 & -2.788688 & 28.5 \\
C42 H41 N4 O4 & 665.312233 & 2.167348 & 3.257627 & 24.5 \\
C34 H49 O13 & 665.316769 & -2.3687 & -3.560269 & 10.5 \\
C34 H42 N8 O5 Na & 665.317038 & -2.638064 & -3.965136 & 17.5 \\
C28 H46 N6 O11 Na & 665.311678 & 2.721952 & 4.091223 & 8.5 \\
C21 H50 N6 O16 Na & 665.317551 & -3.151408 & -4.736716 & -0.5 \\
C41 H38 N8 Na & 665.311165 & 3.235296 & 4.862804 & 26.5 \\
C50 H42 Na & 665.317873 & -3.4728 & -5.219784 & 29.5 \\
C41 H45 O8 & 665.310895 & 3.50466 & 5.267671 & 19.5 \\
C35 H45 N4 09 & 665.318106 & -3.706012 & -5.570312 & 15.5 \\
C27 H50 N2 O15 Na & 665.310341 & 4.059264 & 6.101267 & 3.5 \\
C25 H45 N8 O13 & 665.310061 & 4.339396 & 6.522319 & 7.5 \\
C22 H46 N10 O12 Na & 665.318889 & -4.48872 & -6.74676 & 4.5 \\
C40 H42 N4 O4 Na & 665.309827 & 4.572608 & 6.872847 & 21.5 \\
C38 H37 N10 O2 & 665.309547 & 4.85274 & 7.293899 & 25.5
\end{tabular}

Figure S12. HRMS spectrum of compound 3. 